\title{
Health-profession students' teaching and learning expectations in Ugandan medical schools: pre- and postcommunity placement comparison
}

This article was published in the following Dove Press journal:

Advances in Medical Education and Practice

8 December 2015

Number of times this article has been viewed

\section{Edith K Wakida \\ Gad Ruzaaza' \\ Kintu Muggaga ${ }^{2}$ \\ Peter Akera $^{3}$ \\ Hussein Oria ${ }^{4}$ \\ Sarah Kiguli ${ }^{4}$}

'Medical School, Mbarara University of Science and Technology,

Mbarara, ${ }^{2}$ Medical School, Kampala

International University, Kampala,

${ }^{3}$ Medical School, Gulu University, Gulu,

${ }^{4}$ Medical School, Makerere University

Kampala, Kampala, Uganda

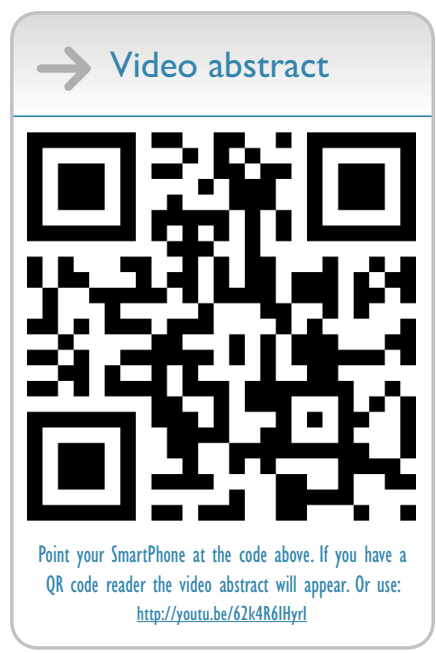

Correspondence: Edith K Wakida Mbarara University of Science and Technology, PO Box 1410, Mbarara University Road, Mbarara 00256, Uganda

Tel +256 78268554 l

Email ediwakida@must.ac.ug
Purpose: The benefits of community-based medical education for both students and teachers are becoming increasingly clear. However, there is paucity of information about the importance of incorporating students' thoughts in the community-based education curriculum and the impact it has on their intentions to work in rural communities. The purpose of this study was to assess the teaching and learning expectations before and after placement of health-profession students going for community placement for the first time and make suggestions for improvement of the community-based programs.

Methods: The study was a cross-sectional survey with both structured and unstructured questions. Participants were recruited from four medical schools in Uganda targeting 100\% participation of health-profession students going for community placement in 2014. In total, 454 and 305 participants responded to self-administered questionnaires before and after community placement, respectively; and they were from different programs and years of study.

Results: Students' learning expectations before placement, in ranking were: community engagement, interpersonal skills, community diagnosis, clinical skills, lifestyle practices, and patient management. After placement, the order of ranking was: interpersonal skills, community engagement, community diagnosis, lifestyle practices, clinical skills, and patient management. Most of the students had prior rural exposure and expected to do community engagement. However, after community placement they indicated having developed interpersonal skills. The various health-profession students were able to harmoniously work together to achieve a common purpose, which they find difficult to do in a classroom environment.

Conclusion: Having student teams comprised of different health programs and years of study going for community placement together promoted peer-to-peer mentorship and enhanced team building during community placement.

Keywords: Minimum competencies, MESAU, community based education and Uganda, community-based education

\section{Introduction}

Community-based education (CBE) involves shifting teaching and learning from a lecture room into the community to interface with the needs of host communities. The benefits of community-based medical education for both students and teachers are becoming increasingly clear. ${ }^{1}$ These include community capacities built to address future health and social issues, enjoyment of the practice of medicine, time spent reviewing clinical medicine, desire to keep up with recent developments in medicine, and understanding the link between theory and practice. ${ }^{2-4}$ In order to meet the current health workforce needs, global health leaders have called on training institutions to scale 
up the production of health workers with curricula that are community-, competency-, and team-based. ${ }^{5}$ This is because innovations in medical education are leading to the emergence of transformative learning where emphasis is on professional competencies such as clinical/practical skills, communication skills, leadership, professionalism, and ethical practice as opposed to focusing on knowledge only. ${ }^{6}$ National reports of both practitioners and academicians have called for more competency-driven, interdisciplinary-focused, communitybased, service-oriented, and experientially-guided learning for students across the curriculum. ${ }^{7,8}$ In Uganda, reducing the disease burden and addressing health challenges require Ugandan medical schools to produce health workers with the necessary competencies. ${ }^{9}$ Consequently, in 2011, five medical schools in Uganda formed the Medical Education for Equitable Services for All Ugandans (MESAU) consortium to address the medical education challenges in meeting the nation's health needs. ${ }^{6,10}$ Through detailed consultations with stakeholders and a series of meetings, workshops, and seminars, the MESAU consortium came up with nine key competency domains for all the five medical schools to be incorporated into the various medical school curricula with an aim of producing graduates with common attributes. ${ }^{6}$

The consortium, comprised of Makerere College of Health Sciences (MakCHS), Mbarara University of Science and Technology (MUST), Busitema University, Gulu University, and Kampala International University (KIU), with support from the Medical Education Partnership Initiative ${ }^{11}$ has created opportunities for students to interact with communities to engender enthusiasm about service in underserved communities $^{12}$ through CBE.

However, there is paucity of information about the importance of incorporating students' thoughts in the CBE curriculum and the impact it has on their intentions to work in rural communities. Analyzing the effectiveness of CBE in light of the health-profession students' teaching and learning expectations before and after community placement is very important in increasing the number and retention of highquality committed health workers in underserved areas.

The aim of this study was to assess the teaching and learning expectations of health-profession students going for community placement for the first time before community placement and compare their views upon returning from the placement. The rationale was to make suggestions for improvement of community-based programs with an assumption that they are an incentive for the health-profession students' intentions to work in rural communities.
The main issues addressed in this paper are 1) students' learning expectations while in the community, 2) motivators for the teaching and learning experience, and 3) ideal length of stay in the community and the number of exposures.

Throughout this paper, the health-profession students refers to students in the medical school regardless of the program offered.

\section{Methods Research approach}

This study was a cross-sectional survey with both structured and open-ended questions. The rationale of a cross-sectional study was to determine the frequency of attributes to the study variables. It was considered that the unstructured responses would usefully supplement and extend the structured analysis. The first set of data collection was done using a self-administered questionnaire just before the orientation program for community placement commenced; the other data were collected after community placement. Prior to data collection, the tool was pretested and edited to take care of the existing gaps and irregularities.

\section{Participants' characteristics}

Participants were recruited from four medical schools in Uganda located in the North (Gulu University), Central (MakCHS), and southwestern (MUST and KIU) regions covering urban and semiurban areas. Eligibility criteria were health-profession students going for community placement for the first time in 2014. The medical schools conduct orientation programs for health-profession students prior to community placement. Interviews were therefore carried out before the orientation program commenced, debriefing students about what to expect in the community.

In order to obtain the health-profession students' perceptions across the four medical schools, the study targeted $100 \%$ participation of individuals going for community placement in 2014 since the exact number of students was not originally known. At the data collection stage, the actual numbers of students going for community placement were established, and the overall response rate was kept at $75.1 \%$.

The study population comprised of first-year healthprofession students from MakCHS and KIU; second-year Pharmacy students, third-year Medical Laboratory Science students, third-year Nursing Science students, and fourth-year MBChB students from MUST; and fourth-year MBChB students from Gulu University Medical School. 


\section{Data collection}

Prior to commencing the study, ethical clearance was sought from Mbarara University of Science and Technology Research Ethics Committee and the Uganda National Council for Science and Technology (reference number MUIRC 1/7).

Following ethical clearance, permission was sought from respective community placement coordinating team heads to gather information from students before starting the community placement orientation program. The survey tool was pretested for validity and reliability prior to data collection and adjusted accordingly.

The study was introduced to the students explaining its importance. Upon obtaining written informed consent, the healthprofession students were invited to respond to a 20-minute precoded questionnaire which they returned soon after completion. Participants were requested to memorize and safely store the code on the questionnaire as it was required again when responding to the postcommunity placement questionnaire. This exercise was repeated across the four study sites whenever the students were preparing to go for community placement in 2014. Respective medical schools, depending on their academic calendar, take students for community placement at different times of the year.

Each study participant was invited to respond to the questionnaire twice during the study period (Figure S1 and S2). The first questionnaire (pre) was administered prior to community placement and the second (post) was administered soon after community placement.

The health-profession students go to different community sites all over Uganda. With the help of the community program coordinators, lists of placement sites were obtained indicating the team leaders. These team leaders were co-opted as research assistants to gather data after community placement. They were trained on what to do and given consent forms which were to be filled prior to receiving a questionnaire. Consent forms and questionnaires were packed in parcels according to the number of students per community site irrespective of whether they were all to be filled or not. The rationale of sending the questionnaires to the community sites was to gather information from the participants when their experience was still fresh because after community placement, students go home on recess.

The post questionnaires and consent forms were delivered to us at the respective study sites as soon as the team leaders returned from the community placement sites. These questionnaires were in turn given to the corresponding author for data management and analysis. Each study site had a coinvestigator who is an author of this paper.

\section{Data analysis procedures}

Data management and analysis were performed using Microsoft Excel and STATA 12 statistical software (StataCorp, College Station, TX, USA). Data from the questionnaires were entered in Microsoft Excel files per medical school before and after community placement. The quantitative questions from excel were then exported to STATA 12 (StataCorp), cleaned, and validated. The open-ended responses were transferred to a Microsoft Word document for thematic coding.

The quantitative questions were analyzed per medical school and then as a combination of the four medical schools for frequencies and percentages, which were presented in tables, pie charts, and bar graphs.

The open-ended responses were analyzed before and after community placement under common themes which were assigned codes, manually recorded, and counted. The number of times a response appears does not reflect the number of participants in the study but the frequency it appears. The open-ended questions were used to gather expanded response to the quantitative questions; participants therefore could have multiple responses to each question.

\section{Results}

Before community placement, the study had 454 respondents with a distribution of 263 (57.93\%) from MUST, 78 (17.18\%) from KIU, 84 (18.5\%) from MakCHS, and 29 (6.39\%) from Gulu University. After community placement, out of the 305 respondents, 186 (60.98\%) responses were from MUST, 55 (18.03\%) from KIU, 42 (13\%) from MakCHS, and 22 (7.21\%) from Gulu University. Of the responses, at precommunity placement, the study had 141 (33\%) females and 289 (67\%) males while at postcommunity placement, 97 (33\%) females and $194(67 \%)$ males.

Overall, there were 192 (43\%) first-year students at precommunity placement and $108(36 \%)$ at postcommunity placement; 66 (15\%) second-year students pre- and 43 (14\%) postcommunity placement; 92 (21\%) third-year students pre- and 77 (25\%) postcommunity placement; 92 (21\%) fourth-year students pre- and 73 (24\%) postcommunity placement; and $1(0.2 \%)$ fifth-year students pre- and $2(0.6 \%)$ postcommunity placement.

\section{Students' learning expectations while in the community}

In response to what the health-profession students expected to learn while in the community ( $\mathrm{n}=$ frequency), most responses 
(159) before community placement indicated community engagement, then interpersonal skills (130), community diagnosis (93), clinical skills (89), lifestyle practices (60), and patient management/understanding systems (54). Upon return from community placement, most responses (127) indicated interpersonal skills, then community engagement (70), community diagnosis (68), lifestyle practices (67), clinical skills (63), and patient management (29).

At precommunity placement when asked how they expected their lives to be affected, 63 respondents listed gaining knowledge and skills; rural exposure (110); attitude change and opportunities (106); and interpersonal, communication and leadership skills (76). After community placement, majority of the responses (93) indicated that community placement had impacted their lives through interpersonal, communication, and leadership skills; knowledge and clinical skills (82); rural exposure (79); and attitude change and opportunities (77).

In reference to minimum competencies set by MESAU, the respondents were asked why they thought community placement was good for them as health-profession students before and after community placement. Table 1 details the benefits and how the participants responded. Exposure through community engagement featured 23 times at pre- and 91 times postcommunity placement among the responses although it is not among the minimum competencies.

The students were asked to what extent they agreed or disagreed with the minimum competencies in relation to their training before and after community placement. Segregated by medical schools, Table 2 presents the minimum competencies and how the health-profession students agreed or disagreed with the statement.

Table I Health profession students views on the benefits of community placement, pre- and postcommunity placement

\begin{tabular}{lll}
\hline & $\begin{array}{l}\text { Precommunity } \\
\text { placement (n) }\end{array}$ & $\begin{array}{l}\text { Postcommunity } \\
\text { placement (n) }\end{array}$ \\
\hline $\begin{array}{l}\text { Medical knowledge } \\
\text { Clinical skills and patient care }\end{array}$ & 17 & 6 \\
$\begin{array}{l}\text { Critical inquiry and scientific } \\
\text { method }\end{array}$ & 4 & 85 \\
$\begin{array}{l}\text { Professionalism and ethical } \\
\text { practice }\end{array}$ & 107 & 12 \\
$\begin{array}{l}\text { Interpersonal and } \\
\text { communication skills }\end{array}$ & 104 & 7 \\
$\begin{array}{l}\text { Leadership and management } \\
\text { skills }\end{array}$ & 30 & 31 \\
$\begin{array}{l}\text { Population health } \\
\text { Reflective practice }\end{array}$ & 0 & 59 \\
Health system management & 35 & 55 \\
\hline
\end{tabular}

\section{Necessities and motivators for teaching and learning experience while in the community placement}

Before community placement, students listed the following requirements as necessary for their learning during community placement: infrastructure, including transport and accommodation (260 responses); basic supplies, including water, electricity, food, and security (244); money (188); working tools, including blood pressure (BP) machines, boots, cameras, and stationery (127); supervisors/mentors (79); medical supplies (53); and interpreters (23).

After community placement, the highest mentioned necessities were working tools, including BP machines, boots, cameras, and stationery (136 responses), followed by infrastructure (transport and accommodation) and money, each with 110 responses; basic supplies including water, electricity, food, and security (93); supervisors/mentors (65); and interpreters (20).

The interactive teaching and learning methods the students considered suitable while in the community for placement were group learning with discussions (192 responses), demonstrations/medical illustrations (85), problem-based learning with case studies (65), community engagement (62), using questions/interviews (60), and lectures (33). After community placement, group learning with discussions still had the majority of responses, (138), followed by demonstrations/medical illustrations (112), questions/interviews (67), community engagement (48), lectures (31), and problembased learning with case studies (19).

\section{Motivators}

Students who took part in the study (preplacement) indicated basic requirements (food, water, shelter, and power) and money as the major motivators for their teaching and learning experience during community placement with 180 responses each; infrastructure (transport and accommodation) had 160 responses, availability of supervisors (90), team work (35), and cooperative community (28).

After community placement, money and infrastructure had the most responses of 178 and 124, respectively, followed by basic requirements (food, water, shelter, and power) and supervisors at 116 and 87 , respectively, cooperative community (48), and team work (23).

\section{Ideal length for community placement}

Table 3 shows the combined respondents' ideal length of stay in the community to learn enough and practice skills. 
Table 2 Minimum competencies rated per medical school in Uganda

\begin{tabular}{|c|c|c|c|}
\hline $\begin{array}{l}\text { Minimum } \\
\text { competencies }\end{array}$ & Response & $\begin{array}{l}\text { Precommunity, } \\
\text { n (\%) }\end{array}$ & $\begin{array}{l}\text { Postcommunity, } \\
\text { n (\%) }\end{array}$ \\
\hline \multicolumn{4}{|c|}{ Medical knowledge } \\
\hline \multirow[t]{2}{*}{ Gulu University } & Agreed & $9(33)$ & $22(100)$ \\
\hline & Disagreed & $18(67)$ & $0(0 \%)$ \\
\hline \multirow[t]{2}{*}{ KIU } & Agreed & $76(98.7)$ & $4(98.2)$ \\
\hline & Disagreed & $\mathrm{I}(\mathrm{I} .3)$ & $\mathrm{I}(\mathrm{I} .8)$ \\
\hline \multirow[t]{2}{*}{ MUST } & Agreed & $244(95.31)$ & $182(98)$ \\
\hline & Disagreed & $6(2.34)$ & $3(2)$ \\
\hline \multirow[t]{2}{*}{ MakCHS } & Agreed & $76(93)$ & $40(96)$ \\
\hline & Disagreed & $3(4)$ & - \\
\hline \multicolumn{4}{|c|}{ Clinical skills and patient care } \\
\hline \multirow[t]{2}{*}{ Gulu University } & Agreed & $24(88.9)$ & $19(90)$ \\
\hline & Disagreed & $2(7.4)$ & $0(0 \%)$ \\
\hline \multirow[t]{2}{*}{ KIU } & Agreed & $63(86)$ & $51(93)$ \\
\hline & Disagreed & $5(7)$ & I (2) \\
\hline \multirow[t]{2}{*}{ MUST } & Agreed & $230(90.2)$ & $175(95)$ \\
\hline & Disagreed & $8(3.14)$ & $3(2)$ \\
\hline \multirow[t]{2}{*}{ MakCHS } & Agreed & $65(79)$ & 33 (80.49) \\
\hline & Disagreed & $\mathrm{I}(\mathrm{I} .22)$ & $2(4.88)$ \\
\hline \multicolumn{4}{|c|}{ Critical inquiry and scientific method } \\
\hline \multirow[t]{2}{*}{ Gulu University } & Agreed & $22(8 \mathrm{I} .48)$ & $819(6.36)$ \\
\hline & Disagreed & $2(7.4)$ & I (4.55) \\
\hline \multirow[t]{2}{*}{ KIU } & Agreed & $67(89)$ & $50(93)$ \\
\hline & Disagreed & $5(7)$ & $0(0 \%)$ \\
\hline \multirow[t]{2}{*}{ MUST } & Agreed & $224(88)$ & $174(94.05)$ \\
\hline & Disagreed & $6(2.35)$ & $5(2.7)$ \\
\hline \multirow[t]{2}{*}{ MakCHS } & Agreed & $53(65)$ & $33(80)$ \\
\hline & Disagreed & $6(7)$ & $0(0 \%)$ \\
\hline \multicolumn{4}{|c|}{ Professionalism and ethical practice } \\
\hline \multirow[t]{2}{*}{ Gulu University } & Agreed & $26(96.3)$ & $22(100)$ \\
\hline & Disagreed & - & $0(0 \%)$ \\
\hline \multirow[t]{2}{*}{ KIU } & Agreed & $74(99)$ & $54(98)$ \\
\hline & Disagreed & - & $0(0 \%)$ \\
\hline \multirow[t]{2}{*}{ MUST } & Agreed & $182(7 \mid)$ & $180(97)$ \\
\hline & Disagreed & $17(7)$ & $2(1.08)$ \\
\hline \multirow[t]{2}{*}{ MakCHS } & Agreed & 7I (89) & $39(95.12)$ \\
\hline & Disagreed & $2(3)$ & $0(0 \%)$ \\
\hline Interpersonal a & and commu & nication skill & \\
\hline Gulu University & Agreed & $26(96.3)$ & $20(91)$ \\
\hline & Disagreed & - & I (4.55) \\
\hline KIU & Agreed & $67(89)$ & $50(91)$ \\
\hline & Disagreed & $2(3)$ & $4(4)$ \\
\hline MUST & Agreed & $244(96.06)$ & $18 \mid(97)$ \\
\hline & Disagreed & $5(2)$ & $3(2)$ \\
\hline MakCHS & Agreed & $75(91)$ & $41(100)$ \\
\hline & Disagreed & $3(4)$ & $0(0 \%)$ \\
\hline Leadership anc & managem & ent skills & \\
\hline Gulu University & Agreed & $15(58)$ & $16(73)$ \\
\hline & Disagreed & - & $2(10)$ \\
\hline KIU & Agreed & $65(87)$ & $51(93)$ \\
\hline & Disagreed & I (I.33) & $2(4)$ \\
\hline MUST & Agreed & $219(86)$ & $175(95)$ \\
\hline & Disagreed & $9(4)$ & $2(1.09)$ \\
\hline MakCHS & Agreed & $67(82)$ & $37(90.25)$ \\
\hline & Disagreed & $6(7.32)$ & I (2.44) \\
\hline
\end{tabular}

Table 2 (Continued)

\begin{tabular}{|c|c|c|c|}
\hline $\begin{array}{l}\text { Minimum } \\
\text { competencies }\end{array}$ & Response & $\begin{array}{l}\text { Precommunity, } \\
\text { n (\%) }\end{array}$ & $\begin{array}{l}\text { Postcommunity, } \\
\text { n (\%) }\end{array}$ \\
\hline \multicolumn{4}{|c|}{ Population health } \\
\hline \multirow[t]{2}{*}{ Gulu University } & Agreed & $21(78)$ & $18(81.8)$ \\
\hline & Disagreed & $2(2.4)$ & $0(0 \%)$ \\
\hline \multirow[t]{2}{*}{ KIU } & Agreed & $69(92)$ & $52(95)$ \\
\hline & Disagreed & I (I.33) & $0(0 \%)$ \\
\hline \multirow[t]{2}{*}{ MUST } & Agreed & $236(92)$ & $178(96)$ \\
\hline & Disagreed & $3(1.17)$ & $2(1.08)$ \\
\hline \multirow[t]{2}{*}{ MakCHS } & Agreed & $65(79.27)$ & $37(90.25)$ \\
\hline & Disagreed & $4(5)$ & I (2.44) \\
\hline \multicolumn{4}{|c|}{ Continuous improvement of care through reflective practice } \\
\hline \multirow[t]{2}{*}{ Gulu University } & Agreed & $21(80.77)$ & $17(77.28)$ \\
\hline & Disagreed & $3(11.57)$ & I (4.55) \\
\hline \multirow[t]{2}{*}{ KIU } & Agreed & $62(84)$ & $50(91)$ \\
\hline & Disagreed & $2(3)$ & $3(5.46)$ \\
\hline \multirow[t]{2}{*}{ MUST } & Agreed & $216(84)$ & $172(93)$ \\
\hline & Disagreed & $8(3.12)$ & $4(2.17)$ \\
\hline \multirow[t]{2}{*}{ MakCHS } & Agreed & $59(72)$ & $34(83)$ \\
\hline & Disagreed & $4(5)$ & I (2.44) \\
\hline \multicolumn{4}{|c|}{ Health system management } \\
\hline \multirow[t]{2}{*}{ Gulu University } & Agreed & $19(70.37)$ & $18(82)$ \\
\hline & Disagreed & $4(14.82)$ & I (4.55) \\
\hline \multirow[t]{2}{*}{ KIU } & Agreed & $61(84)$ & $46(85)$ \\
\hline & Disagreed & $2(3)$ & $2(4)$ \\
\hline \multirow[t]{2}{*}{ MUST } & Agreed & $188(73.43)$ & $162(88)$ \\
\hline & Disagreed & $12(5)$ & $3(1.63)$ \\
\hline \multirow[t]{2}{*}{ MakCHS } & Agreed & $52(63)$ & $36(88)$ \\
\hline & Disagreed & $7(9)$ & I (7.32) \\
\hline
\end{tabular}

Note: Values do not add to $100 \%$ as participants did not reply to all questions. Abbreviations: KIU, Kampala International University; MUST, Mbarara University of Science and Technology; MakCHS, Makerere College of Health Sciences.

\section{Discussion}

The results presented show that most of the respondents came from MUST, while the least number was from Gulu University. MUST had a large number of participants because they had students from different programs and years of study going for community placement for the first time, while participants of other medical schools were from only one year of study or from the same program. Gulu University had the least

Table 3 Ideal length of stay for health-profession students' community placement

\begin{tabular}{lll}
\hline & $\begin{array}{l}\text { Precommunity } \\
\text { placement, } \mathbf{n}(\%)\end{array}$ & $\begin{array}{l}\text { Postcommunity } \\
\text { placement, } \mathbf{n}(\%)\end{array}$ \\
\hline Less than 4 weeks & $89(20.05)$ & $35(11.63)$ \\
4-5 weeks & $212(47.75)$ & $133(44.19)$ \\
6-7 weeks & $66(14.86)$ & $55(18.27)$ \\
8-10 weeks & $56(12.61)$ & $59(19.6)$ \\
More than I0 weeks & $20(4.5)$ & $19(6.31)$ \\
Unnecessary & $1(0.23)$ & - \\
Total & $444(100)$ & $301(100)$ \\
\hline
\end{tabular}

Notes: There were no responses for 5-6 weeks. Participants did not reply to all questions. 
number of participants because they have very few students admitted to a program at one time. It is however, important to note that almost all the Gulu students due for placement took part in the study.

\section{Students' learning expectations}

The students expected to do community engagement activities like health education, immunization, HIV counseling, and testing, but it turned out that most of them reported development of interpersonal, communication, and leadership skills as evidenced in the postcommunity placement responses. This can be attributed to the different perceptions each one had and the team composition per community site where they were grouped according to different programs and years of study.

Relating to other researchers, student approaches to learning vary from surface approaches to meaningful, deep learning practices ${ }^{13}$ and are related to their perceptions of the learning environment. ${ }^{14}$ Health-profession students were able to harmoniously work together. The students included medicine, nursing science, medical laboratory, and pharmacy students among other programs of study to achieve a common purpose, which is not often done in a classroom environment. It is therefore beneficial for institutions taking health-profession students for community placement to mix programs and years to facilitate mentorship and sharing of best practices among students.

Turning to the medical competencies, some researchers feel the core competencies of undergraduate medical education should be defined universally and be used to guide new curriculum structures. ${ }^{15}$ This is in line with what MESAU did in defining minimum competencies. In this study, all the study participants were going for community placement for the first time but were not at the same level of competencies; the second-, third-, and fourth-year students were in a better position to talk about their teaching and learning expectations than the first-year participants. This scenario created an opportunity for peer teaching, which has been recognized as a valuable and effective approach for learning. ${ }^{16}$ Previous studies have shown that cross-year peer tutoring programs in medical education can enhance the skills of volunteer tutors and learners alike. ${ }^{17}$

\section{Necessities and motivators for teaching and learning experience}

In order to have a meaningful teaching and learning experience during community placement, the health-profession students imagined that infrastructure (transport and accommodation) was the most important. However, after community placement, the most important necessities were working tools (BP machines, boots, cameras, and stationery) to facilitate their teaching and learning experience. The students were able to understand the priorities when faced with the need to practice in a less facilitated environment with group learning as the preferred interactive teaching and learning method.

Before community placement, the students' major motivators were availability of basic requirements like food, water, shelter, power, and money; however, after community placement, money and infrastructure (transport and accommodation) were the important motivators for teaching and learning. The shift in responses was after the students had experienced the rural communities without direct provision and needed to survive beyond the basics of life as a healthprofessional. Money is perceived to change people's motivation and their behavior toward others, ${ }^{18}$ including being a settlement between children's social demands and those of their parents; as a result, the social ecology of money use in both children and their parents sets the stage for value construction of the meaning of money. ${ }^{19}$ The findings from this study are in agreement with other researchers.

Recognizing the need to motivate the health-profession students while in the community to maximize their teaching and learning experiences is important if they are to go back and work in the rural communities. As Marslow's theory states, ${ }^{20}$ a human being is motivated by a hierarchy of needs such as 1) physiological: hunger, thirst, bodily comforts; 2) safety/security: out of danger; 3) belongingness and love: affiliate with others, be accepted; and 4) esteem: to achieve, be competent, gain approval, and recognition. Motivating health-professionals to work in less facilitated communities is paramount for effective and efficient operation.

\section{Ideal length for community placement}

The structure of community placement in Ugandan medical schools is such that there are core activities each student is required to accomplish within a given period of time ranging from 4 to 6 weeks. This time frame is in line with the respondents' overall responses. Within that period, the students are required to conduct an operational research in the course of implementing CBE activities aimed at improving health-care provision. They are given adequate time to practice the skills they have acquired; this leadership and management training model equips the students with knowledge, attitudes, and skills of leading and managing practices.

MUST students preferred two community exposures at different placement sites to gain varied experience as opposed 
to one; KIU students initially indicated three exposures; however, upon return from the community, the majority of students preferred two exposures. The reduction in the preferred number of exposures was influenced by the experience during community placement; the KIU respondents were in their first year of study and did not know what to expect. MakCHS students preferred three exposures, while in Gulu University health-profession students there was a shift from the preferred 6-7 weeks, to various preferences of 4-5 weeks (31.82\%), 6-7weeks(31.83\%), and 8-10weeks (31.38\%); however, upon return they had equally divided varying responses although the students all preferred two exposures. This study did not get the reasons for the variation and recommends investigation into responses. It is important for all the medical schools to revisit the number of exposures for the health-profession students as there is a possibility that they would benefit from comparing the two experiences to make an informed decision about working in the rural communities after school.

\section{Limitations}

The study largely had participants from MUST both at pre- and postcommunity placement (263 participants, $58 \%$ ) and (186 participants, 61\%), respectively. The results presented may not clearly represent the views of health-profession students across the four medical schools in Uganda.

Second, there were a significant number of first-year students (192 participants, 43\%) at precommunity placement and (108 participants, 36\%) postcommunity placement as compared to those from other years of study. These first-year students did not have adequate knowledge in medical education to ably represent the students' teaching and learning expectations.

\section{Conclusion}

Initially, the assumption was that community placement could be an incentive for the health-profession students going for community placement for the first time to work in rural settings; the study however found that most of the participants had prior rural exposure contrary to what the researchers had anticipated, so it is not a significant factor. The key message from the study is that having student teams comprised of different health programs and years of study going for community placement together promotes peer-to-peer mentorship and enhances team building during community placement.

\section{Acknowledgments}

The project described was supported by the MESAU MEPI Programmatic Award through Award Number 1R24TW008886 from the Fogarty International Center. The content is solely the responsibility of the authors and does not necessarily represent the official views of the Fogarty International Center or the National Institutes of Health.

Our appreciation goes out to the community placement coordinating program heads and respective Deans for granting us permission to access the students' precommunity placement, to Dr Wilfred Arubaku who took part in the concept development, and to Josephine Najjuma for participation in the data collection process.

\section{Disclosure}

The authors report no conflicts of interest in this work.

\section{References}

1. Mahoney S, Walters L, Ash J. Urban community based medical education - general practice at the core of a new approach to teaching medical students. Aust Fam Physician. 2012;41(8):631-636.

2. Flicker $\mathrm{S}$. Who benefits from community-based participatory research? A case study of the Positive Youth Project. Health Educ Behav 2008;35(1):70-86.

3. Grayson MS, Klein M, Lugo J, Visintainer P. Benefits and costs to community-based physicians teaching primary care to medical students J Gen Intern Med. 1998;13(7):485-488.

4. Coffey H. "They taught me": the benefits of early community-based field experiences in teacher education. Teach Teach Educ. 2010; 26(2):335-342.

5. Talib ZM, Baingana RK, Sagay AS, Van Schalkwyk SC, Mehtsun S, Kiguli-Malwadde E. Investing in community-based education to improve the quality, quantity, and retention of physicians in three African countries. Educ Health. 2013;26(2):109-114.

6. Mubuuke AG, Mwesigwa C, Maling S, et al. Standardizing assessment practices of undergraduate medical competencies across medical schools: challenges, opportunities and lessons learned from a consortium of medical schools in Uganda. Pan African Med J. 2014;19:382.

7. McCloskey L, Condon R, Shanahan CW, Wolff J, Culler C, Kalish R. Public health, medicine, and dentistry as partners in community health: a pioneering initiative in interprofessional, practice-based education J Public Health Manag Pract. 2011;17(4):298-307.

8. Florence J, Behringer B. Community as classroom: teaching and learning public health in rural Appalachia. J Public Health Manag Pract. 2011;17(4):316-323.

9. Kiguli S, Mubuuke R, Baingana R, et al. A consortium approach to competency-based undergraduate medical education in Uganda: process, opportunities and challenges. Educ Health. 2014;27(2):163-169.

10. Mafigiri DK, Ayebare F, Baingana RK, Okello E, Sewankambo NK Medical Education for Equitable Services for All Ugandans (MESAU) consortium: development and achievements. AcadMed.2014;89(8 Suppl) S65-S68.

11. Frehywot $\mathrm{S}$, Mullan F, Vovides $\mathrm{Y}$, et al. Building communities of practice: MEPI creates a commons. Acad Med. 2014;89(8 Suppl):S45-S49.

12. Manabe YC, Campbell JD, Ovuga E, Maling S, Bollinger RC, Sewankambo N. Optimisation of the Medical Education Partnership Initiative to address African health-care challenges. Lancet Global Health. 2014;2(7):e392. 
13. Minasian-Batmanian LC, Lingard J, Prosser M. Differences in students' perceptions of learning compulsory foundation biochemistry in the health sciences professions. Adv Health Sci Educ Theory Pract. 2005; 10(4):279-290.

14. Parpala A, Lindblom-Ylanne S, Komulainen E, Litmanen T, Hirsto L. Students' approaches to learning and their experiences of the teachinglearning environment in different disciplines. Br J Educ Psychol. 2010;80(Pt 2):269-282.

15. Russ JB, McKenney AS, Patel AB. An identity crisis: the need for core competencies in undergraduate medical education. Med Educ Online. 2013;18:1-2.
16. Evans DJ, Cuffe T. Near-peer teaching in anatomy: an approach for deeper learning. Anat Sci Educ. 2009;2(5):227-233.

17. Buckley S, Zamora J. Effects of participation in a cross year peer tutoring programme in clinical examination skills on volunteer tutors' skills and attitudes towards teachers and teaching. BMC Med Educ. 2007;7:20.

18. Vohs KD, Mead NL, Goode MR. The psychological consequences of money. Science. 2006;314(5802):1154-1156.

19. Sato T. Minding money: how understanding of value is culturally promoted. Integr Psychol Behav Sci. 2011;45(1):116-131.

20. Huitt W. Maslow's hierarchy of needs. Educational Psychology Interactive. Valdosta, GA: Valdosta State University; 2004. 


\section{Supplementary materials}

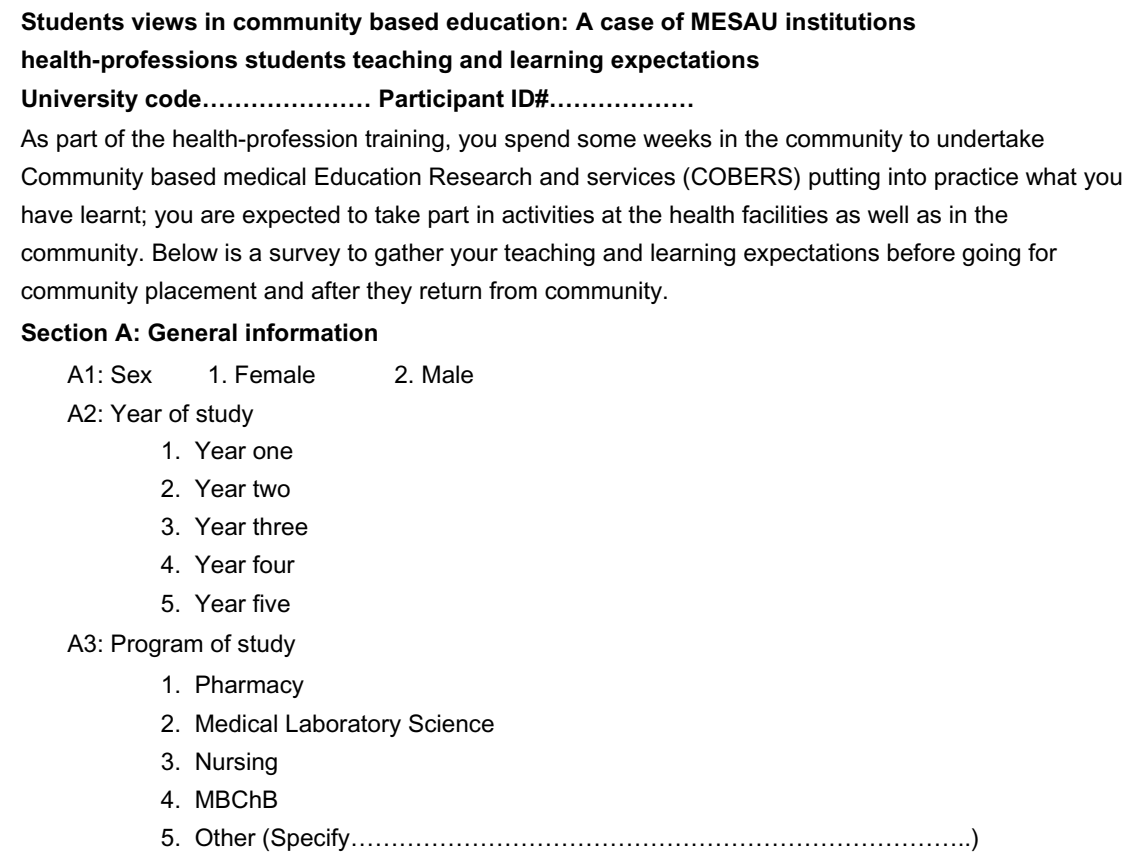

A4: In your entire life, have you ever been in a rural setting to carry out any form of activity?

1. Yes

2. No

A5: What proportion (weeks, months, years) of your life have you spent in

1. Rural setting (specify......

2. Urban setting (specify..................................)

A6: Do you have any fears about community placement?

1. Yes

2. No

A7: Do you think community placement is a good idea for you as a health-profession student?
1. Yes
2. No

A8: In your opinion, what is the ideal length of period for community placement for you to learn enough and practice your skills?

1. Less than 4 weeks

2. 4 to 5 weeks

3. 6 to 7 weeks

4. 8 to 10 weeks

5. More than 10 weeks (specify.

A9: In your opinion, what is the ideal number of community exposures you think you require in your entire study period?

1. One exposure

2. Two exposures

3. Three exposures

4. Other (specify.

Figure SI (Continued) 
Section B: The minimum competencies

The MESAU consortium institutions with participation of Ministries of Education and of Health defined the minimum competencies required for medical education in Uganda. Using the nine MESAU wide competencies in bold letters as a basis, to what extent do you agree or disagree to the statements below?

\begin{tabular}{|c|c|c|c|c|c|c|}
\hline & & $\begin{array}{c}1 \text { Strongly } \\
\text { agree }\end{array}$ & $\begin{array}{l}2 \text { Somewhat } \\
\text { agree }\end{array}$ & $\begin{array}{c}3 \text { Neutral/no } \\
\text { opinion }\end{array}$ & $\begin{array}{c}4 \text { Somewhat } \\
\text { disagree }\end{array}$ & $\begin{array}{r}5 \text { Strongly } \\
\text { disagree }\end{array}$ \\
\hline B1 & $\begin{array}{l}\text { Medical knowledge: I have the } \\
\text { ability to recall knowledge of } \\
\text { human structure, function, } \\
\text { development and Pathophysiology; } \\
\text { and of epidemiological } \\
\text { and social-behavioral sciences } \\
\text { and apply it in providing care } \\
\text { to individuals, families and society }\end{array}$ & & & & & \\
\hline B2 & $\begin{array}{l}\text { Clinical skills and patient care: } \\
\text { I effectively use motor and } \\
\text { cognitive skills to provide appropriate } \\
\text { diagnose, management and } \\
\text { prevention of common health } \\
\text { problems encountered in patient care. }\end{array}$ & & & & & \\
\hline B3 & $\begin{array}{l}\text { Critical inquiry and scientific } \\
\text { method: I understand and use } \\
\text { scientific theory, methodology } \\
\text { and critical thinking skills to } \\
\text { conduct research, interpret } \\
\text { findings and apply these to } \\
\text { improve individual, family and } \\
\text { community health }\end{array}$ & & & & & \\
\hline B4 & $\begin{array}{l}\text { Professionalism and ethical } \\
\text { practice: I demonstrate through } \\
\text { knowledge and behavior a } \\
\text { commitment to the highest } \\
\text { standards of clinical care, ethics, } \\
\text { integrity and accountability to the } \\
\text { patient, society and the } \\
\text { profession }\end{array}$ & & & & & \\
\hline
\end{tabular}

Figure SI (Continued) 


\begin{tabular}{|c|c|}
\hline B5 & $\begin{array}{l}\text { Interpersonal and communication } \\
\text { skill: I demonstrate effective inter- } \\
\text { personal and communication skills } \\
\text { with a wide range of individuals } \\
\text { and groups in order to provide } \\
\text { appropriate health care }\end{array}$ \\
\hline B6 & $\begin{array}{l}\text { Leadership and management } \\
\text { skills: I have appropriate } \\
\text { leadership and management skills } \\
\text { for effective and efficient health } \\
\text { systems }\end{array}$ \\
\hline B7 & $\begin{array}{l}\text { Population health: I have the } \\
\text { ability to work with the } \\
\text { community to promote health, } \\
\text { prevent disease and empower } \\
\text { communities in order to produce a } \\
\text { healthy population }\end{array}$ \\
\hline B8 & $\begin{array}{l}\text { Continuous improvement of } \\
\text { care through reflective } \\
\text { practice: I have the ability to } \\
\text { investigate and evaluate practice, } \\
\text { appraise and assimilate scientific } \\
\text { evidence, and to continuously } \\
\text { improve health care based on } \\
\text { constant self-evaluation and } \\
\text { lifelong learning }\end{array}$ \\
\hline B9 & $\begin{array}{l}\text { Health systems management } \\
\text { I understand the composition, } \\
\text { organization, economics and other } \\
\text { interrelated dynamics components } \\
\text { of health service provision and } \\
\text { the ability to practice within the } \\
\text { health system }\end{array}$ \\
\hline
\end{tabular}

Figure SI (Continued) 
Section C:

C1: What form of activity have you carried out in a rural setting if any?

C2: What are your fears about community placement if any?

C3: If you have no fears, what is the source of your confidence?

C4: What do you expect to learn when you go to the community?

C5: How do you expect COBERS placement to affect your life?

C6: Why do you think community placement is good for you as a health-profession student?

C7: List requirements which you consider necessary to facilitate your learning during community placement?

C8: What is your opinion about the nine competencies in questions Section B above?

C9: List the interactive teaching and learning methods you would consider suitable for you while in the community for placement?

C10: In your opinion, list the most important 5 items you would consider as motivators (wish to have)

for your learning experience while for COBERS placement

Figure SI Pre-community placement questionnaire.

Abbreviation: MESAU, Medical Education for Equitable Services for All Ugandans. 
Students views community based education: A case of MESAU institutions health

professions students teaching and learning expectations

University code.

Participant ID\#.

As part of the health-profession training, you spend some weeks in the community to undertake Community based medical Education Research and services (COBERS) putting into practice what you have learnt; you are expected to take part in activities at the health facilities as well as in the community. Below is a survey to gather your teaching and learning expectations before going for community placement and after they return from community.

\section{Section A: General information}

$\begin{array}{lll}A 1 \text { : Sex } & \text { 1. Female } & \text { 2. Male }\end{array}$

A2: Year of study
6. Year one
7. Year two
8. Year three
9. Year four
10. Year five

A3: Program of study
6. Pharmacy
7. Medical laboratory science
8. Nursing
9. $\mathrm{MBChB}$

A4: In your entire life, have you ever been in a rural setting to carry out any form of activity?
3. Yes
4. No

A5: What proportion (weeks, months, years) of your life have you spent in
3. Rural setting (specify. ....)
4. Urban setting (specify

A6: Did you have any fears about community placement?

3. Yes

4. No

A7: Do you think community placement is a good idea for you as a health-profession student?

3. Yes

4. No

A8: In your opinion, what is the ideal length of period for community placement for you to learn enough and practice your skills?
6. Less than 4 weeks
7. 4 to 5 weeks
8. 6 to 7 weeks
9. 8 to 10 weeks
10. More than 10 weeks (specify

A9: In your opinion, what is the ideal number of community exposures you think you require in your entire study period?

5. One exposure

6. Two exposures

7. Three exposures

8. Other (specify. ..)

Figure S2 (Continued) 
Section B: Tminimum competencies

The MESAU consortium institutions with participation of Ministries of Education and of Health defined the minimum competencies required for medical education in Uganda. Using the nine MESAU wide competencies in bold letters as a basis, to what extent to you agree or disagree to the statements below?

\begin{tabular}{|c|c|c|c|c|c|c|}
\hline & & $\begin{array}{l}1 \text { Strongly } \\
\text { agree }\end{array}$ & $\begin{array}{l}2 \text { Somewhat } \\
\text { agree }\end{array}$ & $\begin{array}{c}3 \text { Neutral/no } \\
\text { opinion }\end{array}$ & $\begin{array}{c}4 \text { Somewhat } \\
\text { disagree }\end{array}$ & $\begin{array}{r}5 \text { Strongly } \\
\text { disagree }\end{array}$ \\
\hline B1 & $\begin{array}{l}\text { Medical knowledge: I have the } \\
\text { ability to recall knowledge of human } \\
\text { structure, function,development } \\
\text { and Pathophysiology; and of } \\
\text { epidemiological and social- } \\
\text { behavioral sciences and apply it in } \\
\text { providing care to individuals, } \\
\text { families and society }\end{array}$ & & & & & \\
\hline B2 & $\begin{array}{l}\text { Clinical skills and patient care: } \\
\text { I effectively use motor and } \\
\text { cognitive skills to provide } \\
\text { appropriate diagnose, } \\
\text { management and prevention of } \\
\text { common health problems } \\
\text { encountered in patient care }\end{array}$ & & & & & \\
\hline B3 & $\begin{array}{l}\text { Critical inquiry and scientific } \\
\text { method: I understand and use } \\
\text { scientific theory, methodology } \\
\text { and critical thinking skills to } \\
\text { conduct research, interpret } \\
\text { findings and apply these to } \\
\text { improve individual, family and } \\
\text { community health }\end{array}$ & & & & & \\
\hline B4 & $\begin{array}{l}\text { Professionalism and ethical } \\
\text { practice: I demonstrate through } \\
\text { knowledge and behavior a } \\
\text { commitment to the highest } \\
\text { standards of clinical care, ethics, } \\
\text { integrity and accountability to the } \\
\text { patient, society and the profession }\end{array}$ & & & & & \\
\hline
\end{tabular}

Figure S2 (Continued) 


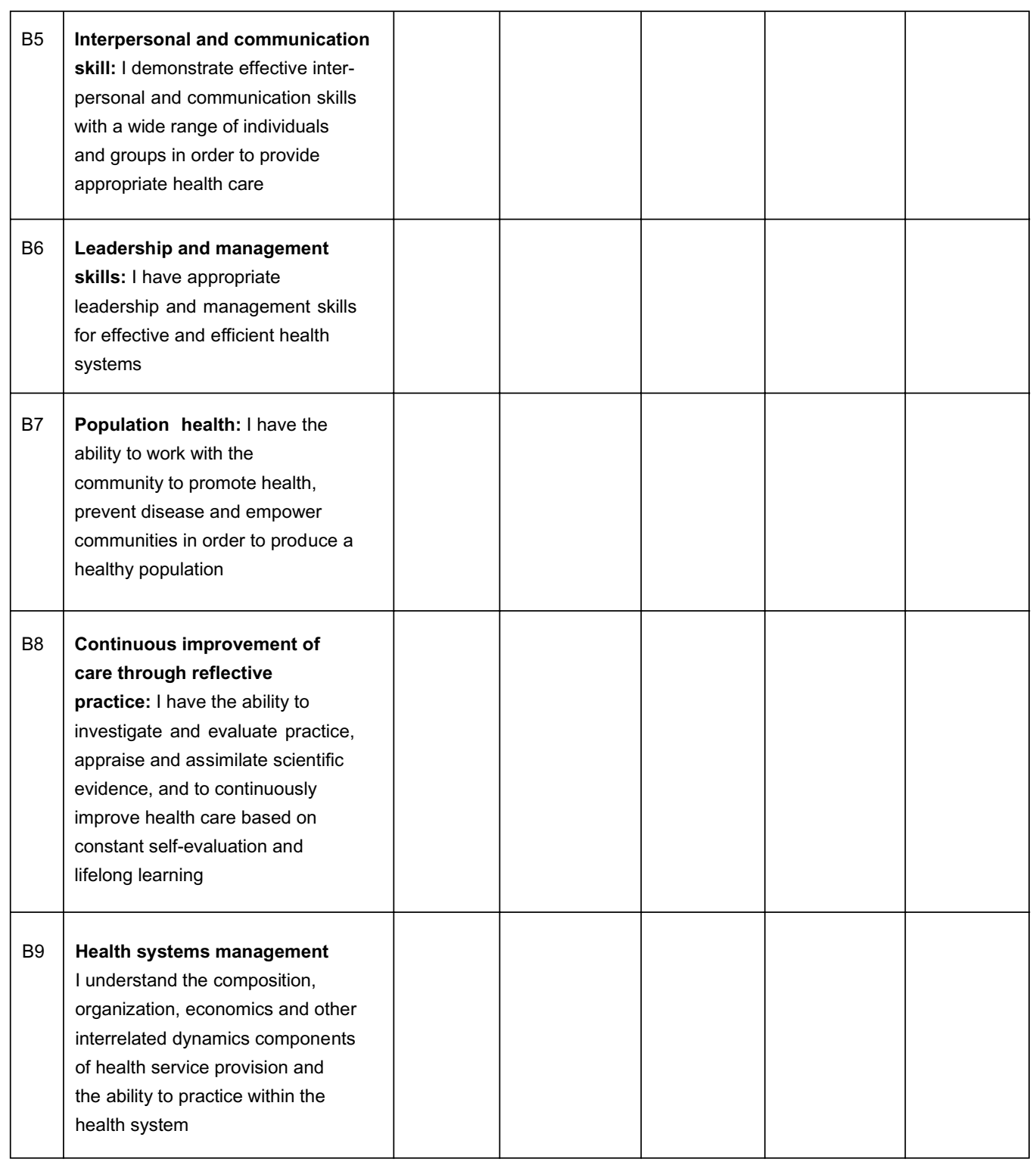

Figure S2 (Continued) 


\section{Section C:}

C1: What activities did you carry out in a rural setting if any?

C2: What were your fears about community placement if any?

C3: If you had no fears, what was the source of your confidence?

C4: What did you learn while in the community?

C5: How did COBERS placement affect your life?

C6: Why do you think community placement is good for you as a health-profession student?

C7: List requirements which you consider necessary to facilitate your teaching and learning during

community placement?

C8: What is your opinion about the nine competencies in questions Section B above?

C9: List the interactive teaching and learning methods you would consider suitable for you while in the

community for placement?

C10: In your opinion, list the most important 5 items you would consider as motivators for your

teaching and learning experience while for COBERS placement

Figure S2 Post-community placement questionnaire.

Abbreviation: MESAU, Medical Education for Equitable Services for All Ugandans.

Advances in Medical Education and Practice

Dovepress

\section{Publish your work in this journal}

Advances in Medical Education and Practice is an international, peerreviewed, open access journal that aims to present and publish research on Medical Education covering medical, dental, nursing and allied health care professional education. The journal covers undergraduate education, postgraduate training and continuing medical education including emerging trends and innovative models linking education, research, and health care services. The manuscript management system is completely online and includes a very quick and fair peer-review system. Visit http://www.dovepress.com/testimonials.php to read real quotes from published authors.

Submit your manuscript here: http://www.dovepress.com/advances-in-medical-education-and-practice-journal 